Print ISSN: 2288-4637 / Online ISSN 2288-4645

doi:10.13106/jafeb.2020.vol7.no12.783

\title{
Explaining Dividend Payout: Evidence from Malaysia's Blue-Chip Companies
}

\author{
Norliza CHE-YAHYA ${ }^{1}$, Siti Sarah ALYASA-GAN ${ }^{2}$
}

Received: September 10, 2020 Revised: November 02, 2020 Accepted: November 16, 2020

\begin{abstract}
This research investigates the explanatory factors governing the dividend payout to shareholders of blue-chip companies listed on Bursa Malaysia. In spite of continuous attention offered by empirical research on dividend payout of publicly-listed companies, paradoxically only few studies exclusively examined the explanatory factors from the perspective of blue-chip companies. Recognizing the capability of bluechip companies to serve as a stalwart indicator of stock market condition as well as a consistent income source to shareholders, more research should be carried out for better inference on the companies' dividend payout decision. This research is using 522 observations from a sample of 18 Malaysian blue-chip companies over a 29-year period (1990 to 2019) and utilizes a panel data regression analysis for the estimation of the impact of eight factors, namely, systematic risk, leverage, free cash flow, lagged dividends, market-to-book value, profit growth, total asset turnover, and company size. Measuring dividend payout using two specifications (dividend/earnings and dividend/total assets), this research reveals that systematic risk and free cash flow have a significant and negative impact on dividend payout. Meanwhile, past year dividends, market-to-book value, profit growth, total asset turnover and company size have a significant and positive impact on dividend payout.
\end{abstract}

Keywords: Dividend Payout Decision, Blue Chip Companies, Malaysian Market

JEL Classification Code: G11, G32, G35

\section{Introduction}

Dividend is a pre-share payment arranged by a company to its shareholders. Dividend can be in the form of cash or stock issue where cash involves the payment to be in terms of monetary, while stock issue is the distribution of free ordinary shares to existing shareholders in addition to current ownership. The amount of dividend paid to shareholders usually is based on a dividend policy of a company (Salman, 2019), a policy structured by a company's board of directors, which is concerned with the distribution of earnings to

${ }^{1}$ First Author and Corresponding Author. Senior Lecturer, Faculty of Business and Management, Universiti Teknologi MARA, Malaysia [Postal Address: Universiti Teknologi MARA Cawangan Selangor, Kampus Puncak Alam, 42300 Bandar Puncak Alam, Selangor, Malaysia] Email: norliza9911@uitm.edu.my

${ }^{2}$ Faculty of Business and Management, Universiti Teknologi MARA, Malaysia. Email: sarahgan29@outlook.com

(c) Copyright: The Author(s)

This is an Open Access article distributed under the terms of the Creative Commons Attribution Non-Commercial License (https://creativecommons.org/licenses/by-nc/4.0/) which permits unrestricted non-commercial use, distribution, and reproduction in any medium, provided the original work is properly cited. shareholders. Dividend policy is also regarded as the decision affecting earnings that are payable to shareholders after all costs and taxes are removed from the company's total earnings (Turakpe \& Fiiwe, 2017). There is an on-going controversy in paying out dividends to the shareholders, as some may believe retaining earnings for profitable investment purposes will be more beneficial to the company in the long run. Others might, however, believe that serving shareholders with high amount of dividend is preferable as it can be an indication of the company's financial strength and growth. Regardless, the issue centering on dividend policy remains on the factors affecting a company's decision to distribute dividend to its shareholders. Research on dividend policy for publicly-listed companies are considered common, however, to highlight blue chip companies as a sample is unusual and scant that many researchers have found little significant to investigate.

Blue-chip companies are universally recognized as well-established and financially sound companies. In Malaysia, a company is branded as a blue-chip company if its market capitalization has reached RM10bn (Eusoff, 2018). Although other factors such as profitability, liquidity and maturity of the companies are considerable 
in designating a company as a blue-chip company, however, in most instances, market capitalization will be the dominant indicator because it defines the worth of companies on the stock market where the larger the market capitalization, the more valuable and defensible a company is to market downturn (Kumar, 2019; Teo et al., 2019). Many investors find that only stocks of blue-chip companies, during the financial crisis from 1997 to 1999, were relevant as a safe and stable investment. In spite of the wide acknowledgements that stocks of blue-chip companies were more stable and often traded resiliently during the period of market downturn, however, demands for their shares will reduce once the economic is in a safer zone, with investors demanding other alternatives rather than stocks of blue-chip companies.

Following Price (2011), blue-chip companies' stocks have fallen behind since 2000, due to a stretch of underperformance compared to stocks with small capitalization. This has caused investors to shift, to an extent, their interest onto other market's highest quality stocks. As a result, blue-chip companies' stocks will no longer be the ultimate preference and leading the market. Irrespective, the under-attention to stocks of blue-chip companies should not be the main rationale in overlooking potential rewards offered from these most prominent companies. In fact, these companies offer desirable quality and safety that can assist the shareholders to sustain longterm returns from a diversified equity portfolio. Some key characteristics of blue-chip companies including an experienced management team, which can adeptly allocate capital, manage expenses, disperse operational risks and sustain steady revenue, and earnings growth should be made visible for investors to be optimistic. Due to their size, blue-chip companies will also benefit from having adequate resources to invest in superior technology with diverse revenue streams, while sustaining their status as the leading companies in the industry and the feasible current income providers to shareholders. Considering these superior features of blue-chip companies, particular attention to the analysis of dividend policy from the sample of these companies must be given by researchers.

Hafeez et al. (2018) suggested that the analysis on the determinants of dividend policy in companies with large market capitalization is more challenging. The treatment of the companies' dividend policy is observed and managed differently compared to companies with lower market capitalization, which was mainly due to the concern on the conflict between companies' long-term growth objectives and the financial obligations of short-term investors. As such, common factors significantly found to affect dividend policy of smaller market capitalization companies may not be applicable to companies with large market capitalization.
Several theoretical models have been developed by researchers, universally, to explain the dividend decision in a company, but possibly a little knowledge of the present research has focused exclusively in finding the explanation to dividend payout from the sample of firms with large market capitalization or that are classified as blue-chip companies. As a single theory or predictor is unlikely to explain the dividend payout, the incorporation of several theories including bird-in-the-hand theory (Gordon, 1963; Lintner, 1956), agency cost (Franco \& Miller, 1958), signaling theory (Bhattacharya, 1979) and free cash flow theory (Jensen, 1986) have been presented as primary explanations to dividend payout decision and continue to attract the attention of researchers. In spite of the continuous research on the determinants of dividend policy that have been put in place, yet there is no definite answer on which factors affect the decision of companies paying dividend, consistently. Findings from past research, in terms of the directions and interactions between the factors, vary widely from sample to sample and country to country. The noticeable variety in the findings of past research caused difficulty to find a uniform conclusion on the determinants of dividend payout.

Malaysian stock market is known as one of the most dynamic emerging stock markets in Asia, which has experienced rapid changes on its trading infrastructure. This market comprises 946 publicly-listed companies accessible to any investors with an adequate amount of liquidity to buy securities. Out of the 946 companies, there are approximately 40 large market capitalization companies in 2019 as compared to only 38 companies in 2018 , following criteria on the amount of market capitalization (Eusoff, 2018). Leveraging on the idea of this research that bluechip companies are designated as leading companies in the industry and their dividend policy is observed and managed differently compared to companies with lower market capitalization, the determinants of their dividend payout should be studied in advance of the studies of determinants of dividend payout in Malaysia's overall publicly-listed companies. A benchmark should be set at a certain level for other companies to be conscious on factors to consider in paying out dividends to shareholders. Therefore, a lack of past research on the dividend payout determinants of these blue chip companies, along with the inconsistent findings of past research on the dividend payout, are the main motivations for this research.

This paper consists of five sections. The rest of this paper is structured as follows. Section 2 reviews relevant literature, followed by Section 3 that describes data and methodology used in this research. Section 4 presents and discusses the empirical results and Section 5 presents conclusions drawn from the findings. 


\section{Theoretical Explanations and Empirical Evidences}

It is acknowledged that dividend policy is an issue that receives continuous attention in the research of finance field especially when a company tends to have high retained earnings and managers making decision on the disbursement of cash to shareholders (Yusof \& Ismail, 2016). Lintner (1956) is one earlier researcher investigating dividend policy on which the Lintner' model was developed. Lintner model is an equation to determine the optimal level of dividend policy in a company. The model posits that a company with higher net present value of earnings will pay higher amount of dividend and that sustainability of earnings also influence the dividend payout. Lintner (1956) found his model to have 85 percent accuracy, explaining 26 out of 28 companies' dividend payout with 22 companies considered adjusting the dividend payout year by year, while four others sought to adjust after two to three years. However, even with the undeniable high level of accuracy, other researchers such as Franco and Miller (1958) showed contrasting findings. Franco and Miller (1958) have challenged the theory in addressing the impact of paying out dividends on the value of a firm. Franco and Miller (1958) discussed the condition where companies' financial decision does not affect the value of a company, which was introduced as the Irrelevance theory. The study argued that, in a given perfect market assumption, the value of firm is not related to the firm's capital structure and dividend payout to shareholders.

To elucidate the contrasting understanding, Gordon (1963) and Lintner (1964) developed a theory called Birdin-Hand theory. It explains how investors are risk adverse, as they prefer to be paid dividends rather than the company retaining its capital gains. Investors are believed to be likely paid by the companies with cash dividend payments as compared to higher and sustainable future cash flows derived from retained earnings or capital appreciation. Therefore, "a bird in the hand is worth more than two in a bush". Payments of current dividends could act as a solvency of the investor's uncertainty (Gordon, 1963). The primary implication on the argument of investors' uncertainty is due to the nature of dividends being at a level of low risk, shareholders will tend to result for a discount on the firm's stream of dividend at a rate of return lower which increases the value of a firm's share, proving that dividend payout indeed affects the value of firm. A research by Farrukh et al. (2017) measured performance of a firm using returnon-equity (ROE) revealed consistent findings reflecting the Bird-in-Hand theory in which the study discloses that a company with higher ROE (high firm performance) will result to higher dividend payout.
Another theory, relevant in explaining dividend payout, is Signalling theory. The original model of this theory was introduced by Spence (2002) who posits the presence of two parties and the issue of information asymmetry. Bhattacharya (1979) assumes that information asymmetry causes the investors to experience imperfect information on firms' profitability. Taleb (2019) justifies a firm generally increases their dividend payout as a signal of the devaluation of the firm in the market. There are also other studies on dividend payout that highlight the market condition as a determinant of dividend payout. Okičić and Horvath (2015), studying an underdeveloped stock market (South-East Europe), found only three out of 35 independent variables examined in the paper as significant and they are dividend yield, price to cash flow and earnings per share, further unfolding that more work is required to understand dividend payout of blue chip stocks in these markets. May and Yacob (2016), on the other hand, investigated that company size and past dividends act as the dividend payout determinants in publicly-listed companies in the emerging market of Malaysia, specifically in oil and gas and consumer products industry. Kaźmierska-Jóźwiak (2015) discovered that there is evidence of significant influence of profitability and leverage on dividend payout with Polish listed companies. In addition, Dewasiri et al. (2019)'s findings on past dividends, investment opportunities, profitability and dividend premium were identified as determinants of dividend payout in emerging and developing markets. Thus far, researchers have offered numerous explanations and discussion on the reasons of companies on paying dividends. Attributable to that, however, Baker and Weigand (2015) specified "there is no clear winner among the competing dividend theories, and no single theory nor determinant had become the dominant solution to the dividend puzzle".

\section{Methodology}

\subsection{Sample Procedure and Diagnostic Tests}

The population of this research comprises large market capitalization companies listed on Bursa Malaysia. Out of 946 listed companies as of December 2019, a total of 38 companies have been identified to satisfy the criteria of at least RM10 billion market capitalization (Eusoff, 2018). A total of 20 companies have been excluded following some filtering processes, which this research excludes, such as financial, insurance and REITs companies, companies with missing values and outliers, producing a final sample of 18 listed companies in Main Market of Bursa Malaysia. The exclusion of all financial, insurance and REITs firms is due to the differences in the format presentation of their financial statement. The final sample includes yearly observations of all the companies covering a duration of 29 years (from 1990 
to 2019). The final sample of this research also produces 522 observations from its panel data model. The early 1990s is the beginning of the sample period as it is the period of an aggressive initiative put in place by the Malaysia government to further promote Malaysian stock market as a global financial center (Hill et al., 2013). The removal of the restriction on foreign shareholdings and announcement of a wide-ranging package of incentives have erased prior restrictions on the international supply of capital and encouraged participation of foreign investors in this market. The significant increase of foreign shareholders caused company's management and strategic policies, one aspect is on dividend payout policy, to be significantly affected (Chiang \& Lai, 2015). The year 2019 , the ending period of sample used in this research, is merely due to the latest coverage year.

The data used in this research are gathered from Bursa Malaysia's website and Thomson Reuters' Eikon database. To ensure the reliability of regression results, the gathered data has also gone through the normality, multicollinearity, stationary, heteroscedasticity and endogeneity tests before it is used for regression analysis. Jarque-Bera test is adopted in testing for normality issues. Pearson Correlation Coefficient with the threshold of 0.95 (Williams, 2015) is used to verify the severity of multicollinearity issue. Levin, Lin and Chu (LLC) test, Im, Pesaran and Shin (IPS) test, Fisher ADF test and Phillips-Perron (PP) test, which also corrects for autocorrelation and heteroscedasticity in the errors, are employed to address the issue of unit root. The econometrics modeling of panel data is normally centered on the issue of whether a regression model can be pooled and tested by fixed effects and random effects estimator. In this research, Hausman test, will be applied to discriminate the fixed effects and random effects model and to check the endogeneity issue.

\subsection{Definition and Measurements}

\subsubsection{Dividend Payout and Measurements}

Dividend payout in this research is measured with two different specifications:

i) Dividing sum of dividends by net earnings (Nguyen et al., 2019). This measurement is the representation of relative net earnings distributed to the shareholders of companies. Investors may refer to dividend payout to gauge the income they will earn for each unit of share they invested in relative to every cent of earnings that a company produced in a year. A growing dividend payout implies a falling amount of earning kept on hand for the reinvestment in growth. However, it also indicates that a company's management considers sustainable earnings. A majority of past researches opt to measure dividend payout of companies with this specification.
Dividend payout per net earnings $(D P E)=\frac{\text { Dividend }_{i, t}}{N E_{i, t}}$

Where,

Dividend $_{i, t}=$ Total Dividends for firm (i) in period ( $\mathrm{t}$ )

$N E_{i, t}=$ Total Net Earnings for firm (i) in period (t)

ii) Dividing sum of dividends by total assets (Forti et al., 2015). This measurement is reached by dividing the sum of dividends by the total assets. It the representation of relative level of cash flows distributed to shareholders. In this specification, total assets act as the denominator instead of net earnings as high variation of the latter is not regularly in line with dividend changes as total assets are more stable than earnings. Some companies distribute dividends even when producing only losses. In such instances, while dividends are always positive, dividend payouts will become negative through division with a negative value of company's earning, diametrically changing the regression results. Thus, employing total assets as a denominator eliminates this bias and offers a more reflective explanation to dividend payout (Forti et al., 2015).

Dividend payout pertotal assets $(D P A)=\frac{\text { Dividend }_{i, t}}{T A_{i, t}}$

Where,

Dividend $_{i, t}=$ Total Dividends for firm (i) in period ( $\mathrm{t}$ ) $T A_{i, t}=$ Total Assets for firm (i) in period ( $\mathrm{t}$ )

\subsubsection{Operational Definition of Independent Variables and Regression Models}

This research will assess the variations on dividend payout against eight chosen variables, which are systematic risk (Beta), leverage (DTE), free cash flow (FCF), lagged or past dividends (LDIVD), market-to-book value ratio (MTBV), profit growth (PROGROW), total asset turnover (TATO), and company size (COSIZE). The operational definition of all variables, arguments and expected sign of relationship are summarized in Table 1.

This research employs the following regression models to explain dividend payout.

$$
\begin{aligned}
\text { DPE } & =\alpha+\beta_{1} \text { BETA }_{i}+\beta_{2} \text { DTE }_{i}+\beta_{3} \text { FCF }_{i}+\beta_{4} \text { LDIVD }_{i} \\
& +\beta_{5} \text { MTBV }_{i}+\beta_{6} \text { PROGROW }_{i}+\beta_{7} \text { TATO }_{i} \\
& +\beta_{8} \text { COSIZE }_{i}+\varepsilon_{i} \\
\text { DPA } & =\alpha+\beta_{1} \text { BETA }_{i}+\beta_{2} \text { DTE }_{i}+\beta_{3} \text { FCF }_{i}+\beta_{4} \text { LDIVD }_{i} \\
& +\beta_{5} \text { MTBV }_{i}+\beta_{6} \text { PROGROW }_{i}+\beta_{7} \text { TATO }_{i} \\
& +\beta_{8} \text { COSIZE }_{i}+\varepsilon_{i}
\end{aligned}
$$


Table 1: Summary of Independent Variables and Expected Sign

\begin{tabular}{|c|c|c|c|c|c|}
\hline No. & Variables & Definition & Supporting Arguments & $\begin{array}{l}\text { Exp. } \\
\text { Sign }\end{array}$ & Past Studies \\
\hline 1 & $\begin{array}{l}\text { Systematic } \\
\text { Risk } \\
\text { (BETA) }\end{array}$ & $\frac{\text { covariance }}{\text { variance }}$ & $\begin{array}{l}\text { Companies facing greater } \\
\text { systematic risks and higher } \\
\text { earnings uncertainty - pay } \\
\text { low dividends. }\end{array}$ & $-\mathrm{ve}$ & $\begin{array}{l}\text { Forti et al. (2015), } \\
\text { Issa (2015), Nyere } \\
\text { and Wesson (2019) }\end{array}$ \\
\hline 2 & $\begin{array}{l}\text { Leverage } \\
\text { (DTE) }\end{array}$ & $\frac{\text { Total debt }}{\text { Total equity }}$ & $\begin{array}{l}\text { A credible signal to high } \\
\text { future cash flows - pay } \\
\text { higher dividends. }\end{array}$ & $+\mathrm{ve}$ & $\begin{array}{l}\text { Forti et al. (2015), } \\
\text { Dewasiri et al. } \\
\text { (2019), } \\
\text { May and Yacob } \\
\text { (2016), } \\
\text { Franc-Dąbrowska, } \\
\text { Mądra-Sawicka, and } \\
\text { Ulrichs (2020) } \\
\end{array}$ \\
\hline 3 & $\begin{array}{l}\text { Free Cash } \\
\text { Flow } \\
\text { (FCF) }\end{array}$ & $E B I T \times \frac{1}{\text { Total Assets }}$ & $\begin{array}{l}\text { Companies with more } \\
\text { stable earnings can expect } \\
\text { larger amount of free } \\
\text { cash flows - pay higher } \\
\text { dividends. }\end{array}$ & $+\mathrm{ve}$ & $\begin{array}{l}\text { Issa (2015), Guizani } \\
\text { (2018), } \\
\text { Nyere and Wesson } \\
\text { (2019) } \\
\text { Franc-Dąbrowska } \\
\text { et al. (2020) }\end{array}$ \\
\hline 4 & $\begin{array}{l}\text { Lagged } \\
\text { Dividend } \\
\text { (LDIVD) }\end{array}$ & $\frac{\text { Dividend per share }(t-1)}{\text { Market Value per share }(t-1)}$ & $\begin{array}{l}\text { Companies with a positive } \\
\text { outlook for future cash flows } \\
\text { - will pay higher dividends } \\
\text { than the past year's } \\
\text { dividends. }\end{array}$ & $+\mathrm{ve}$ & $\begin{array}{l}\text { Al-Kayed (2017), } \\
\text { Dewasiri et al. } \\
(2019), \\
\text { May and Yacob } \\
\text { (2016) }\end{array}$ \\
\hline 5 & \begin{tabular}{|l} 
Market \\
to Book \\
Value \\
(MTBV)
\end{tabular} & $\frac{\text { Market capitalization }}{\text { Total bookvalue }}$ & $\begin{array}{l}\text { Markets are expected to } \\
\text { identify companies that offer } \\
\text { superior present and future } \\
\text { cash flows to shareholders. }\end{array}$ & $+\mathrm{ve}$ & $\begin{array}{l}\text { Forti et al. (2015), } \\
\text { Issa (2015), } \\
\text { Dewasiri et al. } \\
(2019)\end{array}$ \\
\hline 6 & $\begin{array}{l}\text { Profit } \\
\text { Growth } \\
\text { (PRO- } \\
\text { GROW) }\end{array}$ & $\frac{\text { Present Net Income }- \text { Previous Net Income }}{\text { Previous Net Income }}$ & $\begin{array}{l}\text { Companies guaranteed } \\
\text { higher future cash flows } \\
\text { - increase dividends. } \\
\text { Companies with higher } \\
\text { profit growth should } \\
\text { mitigate uncertainties facing } \\
\text { managers - pay more } \\
\text { dividends. }\end{array}$ & $+\mathrm{ve}$ & $\begin{array}{l}\text { Forti et al. (2015), } \\
\text { Issa (2015), } \\
\text { Dewasiri et al. } \\
\text { (2019), } \\
\text { Franc-Dabrowska } \\
\text { et al. (2020) }\end{array}$ \\
\hline 7 & $\begin{array}{l}\text { Total Asset } \\
\text { Turnover } \\
\text { (TATO) }\end{array}$ & $\frac{\text { Sales }}{\text { Total Assets }}$ & $\begin{array}{l}\text { Higher TATO implies that } \\
\text { companies have efficiently } \\
\text { used their total assets } \\
\text { (assets } \\
\text { can rotate faster) to } \\
\text { generate sales and profits - } \\
\text { pay higher dividends. }\end{array}$ & $+\mathrm{ve}$ & $\begin{array}{l}\text { Marlim and Arifin } \\
\text { (2015), } \\
\text { Nerviana (2016), } \\
\text { Suharmanto, } \\
\text { Widiyanti, and } \\
\text { Taufik (2019) }\end{array}$ \\
\hline 8 & $\begin{array}{l}\text { Firm Size } \\
\text { (COSIZE) }\end{array}$ & Natural logarithm of total asset & $\begin{array}{l}\text { Larger companies - more } \\
\text { likely to pay higher } \\
\text { dividends to reduce agency } \\
\text { costs and as they are } \\
\text { less sensitive to financial } \\
\text { difficulties. }\end{array}$ & $+\mathrm{ve}$ & \begin{tabular}{|l} 
Forti et al. (2015), \\
Dewasiri et al. \\
(2019), \\
Franc-Dąbrowska \\
et al. (2020) \\
May and Yacob \\
(2016), \\
Tahir and Mushtaq \\
(2016)
\end{tabular} \\
\hline
\end{tabular}

Note: ${ }^{* * *},{ }^{* *}$ and * indicates significant at $1 \%, 5 \%$ and $10 \%$ level of significance based on t-statistics. 
Where, $\alpha$ is constant term, BETA is systematic risk, DTE is debt to equity, FCF is free cash flow, LDIVD is lagged dividend, MTBV is market to book value, PROGROW is profit growth, TATO is total asset turnover, COSIZE is company size and $\mathcal{E}$ is error term.

\section{Empirical Results and Analysis}

\subsection{Descriptive Statistics Results}

Table 2 presents the descriptive statistics of the variables in the final sample of 18 publicly-listed companies, categorized as blue-chip companies, from 2000 to 2019. The mean of DPE and DPA are $45.45 \%$ and $3.56 \%$, ranging from a minimum value of 0 percent to a maximum value of $100 \%$ and $4.30 \%$, respectively. The mean value reports that blue-chip companies in Malaysia will use an average $45.45 \%$ of their earnings into paying dividends to their shareholders and another $54.55 \%$ is held as retained earnings for future use. This indicates that companies with large market capitalization will usually focus more on the long-run motivation, which sustainability of the companies is the priority rather than maximizing the wealth of shareholders. Regardless, the mean of $45.45 \%$ is still considered high, which it offers support to wide acknowledgement that blue-chip companies provide consistent dividends to shareholders over years. On the other hand, a minimum value of $0 \%$ for DPE and DPA show that there is at least one blue-chip company in the sample that does not pay out dividends to shareholders for at least one year, whereas the maximum value of $100 \%$ tells that all of the company's earnings are used into paying dividends to shareholders.

Table 2 also presents the correlation coefficient analysis used to measure the direction and strength of the linear correlation between two variables. An additional purpose of this analysis is to inspect the potential of multicollinearity issue between the explanatory variables. The correlation results display no severe multicollinearity issue as the correlation values of all explanatory variables are very much lower than the threshold (0.95). The highest correlation value of only 0.65 is reported between total asset turnover (TATO) and market-to-book value (MTBV), which the correlation value is revealed to be positive. Apart from signifying the absence of severe multicollinearity issue, the correlation values of the explanatory variables also denote their independency as potential predictors to dividend payout (DPE and DPA).

\subsection{Regression Analysis, Findings and Discussion}

Table 3 presents regression results of this research with the results being separated into Model A (DPE) and Model B (DPA). As stated in previous section, all relevant diagnostic tests have to be conducted before a decision on the finest model to explain the relationship among

Table 2: Descriptive Statistics and Correlations Analysis

\begin{tabular}{|l|c|c|c|c|c|c|c|c|c|c|c|c|c|c|c|}
\hline \multicolumn{10}{|c|}{ Sample Observations (N= 522) } \\
\hline Var & Mean & Min & Max & Std. Dev. & $\begin{array}{c}\mathbf{P} \\
(\mathbf{J B})\end{array}$ & $\mathbf{1}$ & $\mathbf{2}$ & $\mathbf{3}$ & $\mathbf{4}$ & $\mathbf{5}$ & $\mathbf{6}$ & $\mathbf{7}$ & $\mathbf{8}$ & $\mathbf{9}$ & $\mathbf{1 0}$ \\
\hline 1 & 45.45 & 0 & 100 & 0.28 & 0.00 & 1.00 & & & & & & & & & \\
\hline 2 & 3.56 & 0 & 4.30 & 0.06 & 0.00 & 0.00 & 1.00 & & & & & & & & \\
\hline 3 & 0.64 & -0.21 & 2.79 & 0.83 & 0.00 & -0.12 & -0.24 & 1.00 & & & & & & & \\
\hline 4 & 67.89 & -4349.40 & 6821.46 & 0.83 & 0.00 & -0.06 & -0.05 & 0.02 & 1.00 & & & & & & \\
\hline 5 & 0.03 & -2.37 & 1.89 & 0.37 & 0.00 & -0.12 & -0.06 & -0.03 & -0.03 & 1.00 & & & & & \\
\hline 6 & 0.01 & -0.65 & 0.83 & 0.10 & 0.00 & 0.13 & 0.34 & -0.06 & -0.02 & 0.12 & 1.00 & & & & \\
\hline 7 & 3.32 & -2.10 & 52.68 & 5.22 & 0.00 & 0.44 & 0.81 & -0.13 & -0.06 & -0.13 & 0.15 & 1.00 & & & \\
\hline 8 & 20.34 & -28.05 & 714.47 & 55.09 & 0.00 & -0.06 & -0.00 & -0.08 & -0.05 & -0.02 & 0.03 & -0.06 & 1.00 & & \\
\hline 9 & 0.81 & 0.03 & 2.92 & 0.70 & 0.00 & 0.46 & 0.58 & -0.26 & -0.07 & 0.01 & 0.15 & 0.65 & -0.21 & 1.00 & \\
\hline 10 & 12693167 & 97268 & 154000000 & 21657275 & 0.00 & -0.25 & -0.19 & 0.49 & 0.12 & -0.05 & -0.04 & -0.29 & -0.09 & -0.57 & 1.00 \\
\hline
\end{tabular}

Notes: Var $=$ Variables, $\mathrm{P}(\mathrm{JB})=$ Probability $($ Jarque Bera), 1. DPE $=$ Dividend Payout per Earnings $(\%), 2$. DPA $=$ Dividend Payout per Assets, 3. BETA = Systematic Risk, 4. DTE = Debt-to-Equity (\%), 5. FCF =Free Cash Flow, 6. LDIVD = Lagged Dividend, 7. MTBV =Marketto-Book Value, 8. PROGROW = Profit Growth, 9. TATO = Total Assets Turnover and 10. COSIZE = Company Size. 
variables is made. Referring to Hausman test to verify whether fixed-effect model or random-effect model is the fittest model, the results found that the significant level is less than 0.05 , suggesting fixed-effect model as the best model to this research. The regression models report an adjusted R2 of $25.70 \%$ (Model A) and 75.10\% (Model B), indicating that $25.70 \%$ and $75.10 \%$ of variation in DPE and DPA are explained by all the variables used in this research. In spite of having higher variation in dividend payout, the reported R2 in Model B (DPA) should be reflective of the measurement, which claimed to prevent the development of non-existent variations in the dependent variable (Forti et al., 2015). In that case, the selection of variables in explaining dividend payout of Malaysia's blue-chip companies in this research is considered appropriate. In addition, F-statistic values, which are significant at $99 \%$ level (Model A and Model B) also verify that both models are appropriately specified.

Table 3: Regression Results - Fixed Effect Models

\begin{tabular}{|l|c|c|}
\hline \multicolumn{3}{|l|}{ Dependent Variable = Dividend Payout } \\
\hline $\begin{array}{l}\text { Independent } \\
\text { Variables }\end{array}$ & $\begin{array}{c}\text { Model A } \\
\text { Dividend Payout } \\
\text { per Earnings } \\
\text { (DPE) }\end{array}$ & $\begin{array}{c}\text { Model B } \\
\text { Dividend Payout } \\
\text { per Total Assets } \\
\text { (DPA) }\end{array}$ \\
\hline BETA & $-0.020(0.013)$ & $-0.014(-7.612)^{* * *}$ \\
\hline DTE & $-0.002(-0.626)$ & $-0.000(-0.416)$ \\
\hline FCF & $-8.132(-2.695)^{\star * *}$ & $0.002(0.688)$ \\
\hline LDIVD & $16.417(1.460)$ & $0.115(8.640)^{* * *}$ \\
\hline MTBV & $1.123(3.976)^{* * *}$ & $0.008(23.392)^{* * *}$ \\
\hline PROGROW & $-0.08(0.370)$ & $0.000(3.657)^{* * *}$ \\
\hline TATO & $-12.931(5.005)^{* * *}$ & $0.017(5.698)^{* * *}$ \\
\hline COZISE & $-0.314(-0.147)$ & $0.020(8.124)^{* * *}$ \\
\hline Adjusted R & 0.257 & 0.751 \\
\hline $\begin{array}{l}\text { Prob } \\
\text { (F-statistics) }\end{array}$ & 0.000 & 0.000 \\
\hline $\begin{array}{l}\text { Hausman } \\
\text { Test (p-value) } \\
- \text { Fixed effect } \\
\text { models }\end{array}$ & 0.0002 & 0.0003 \\
\hline
\end{tabular}

Notes: DPE $=$ Dividend Payout per Earnings (\%), 2. DPA = Dividend Payout per Assets, 3. BETA = Systematic Risk, 4. DTE = Debt-toEquity (\%), 5. FCF =Free Cash Flow, 6. LDIVD = Lagged Dividend, 7. MTBV =Market-to-Book Value, 8.

PROGROW $=$ Profit Growth, 9. TATO $=$ Total Assets Turnover and 10. COSIZE = Company Size . The reported values are coefficient estimates and t-statistics (reported in parentheses). Asteriks ${ }^{* * *},{ }^{* *}$ and ${ }^{*}$ indicate significance at $1 \%, 5 \%$, and $10 \%$, respectively.
In general, the coefficients of all explanatory variables (in Model A and Model B) satisfy the hypothesized directions' expectations except for DTE in both models, and FCF, TATO and COSIZE in Model A. All the four variables and dividend payout were expected to be positive. However, the regression results in Table 3 exhibit that FCF, TATO and COSIZE inversely influence dividend payout. This research hypothesizes that BETA will have a negative relationship with dividend payout, regardless of measurements. Forti et al. (2015) found that systematic risk (BETA) is negatively related to dividend payout. The relevance is that, when the risk becomes higher, the managers will be reluctant to increase the dividends, hence reducing it instead of increasing the dividends. The results in Table 3 show that BETA is significantly and negatively related to dividend payout in Model B. Referring to the p-value at 0.014, it shows that BETA has a highly significant influence on dividend payout at a confidence level of $99 \%$, indicating that higher risks characteristic correlate with lower firm tendency to pay dividends. In particular, blue-chip companies in Malaysia during the study period will distribute lower dividend when experiencing higher risk, presumably because higher beta denotes the presence of higher stock volatility in relative to overall market. The evidence reflects the view that a greater beta value increases the uncertainty of expected future earnings. Hence, companies with higher systematic risk are forced to pay lower dividends to avoid excessive volatility from the market. This finding revealed that blue-chip companies with volatile earnings pay lower dividends in an attempt to keep their dividend payout stable. The finding of this research reveals no difference with past studies with samples of companies from other criteria (Forti et al., 2015; Issa, 2015; Nyere \& Wesson, 2019).

This research predicts a positive relationship between DTE and dividend payout, regardless of measurements. The finance view is massively attributed to the signaling theory when explaining the influence of DTE on dividend payout. When a company's debt financing increases, the companies will choose to declare high dividends as a credible signal that they will be able to accumulate higher future cash flows (Forti et al., 2015). In this context, managers who are in this position will act to distribute higher dividends. From another view, larger companies more likely to pay higher dividend to reduce agency costs as they are less sensitive to financial difficulties (Dewasiri et al., 2018; May \& Yacob, 2018; Dabrowska et al., 2020). Regardless, this research is not able to support that DTE significantly explain dividend payout of blue chip companies in Malaysia. The negative coefficient sign, although insignificant, seems to imply that companies facing greater risks because of high debt levels are more reluctant to pay high dividends because of future uncertainty of cash flows.

FCF refers to a company excess cash flow available to finance all projects with a positive net present value. 
This research hypothesizes a positive relationship between FCF and dividend payout upon positing that companies with a higher FCF will declare more dividends to reduce agency costs between managers and shareholders, and that managers rely on dividend policy as a communication device with the investors to signal income growth level and future prospects of the company growth (Dabrowska et al., 2020). As shown in Table 3, this research finds a significant relationship between FCF and dividend payout but the significance prevails only in Model A (DPE), with a contradictory sign of relationship. This finding, which does not support the proposition on the use of dividend payout as a device to reduce agency cost and signal income growth, seems to indicate that managers of Malaysia's blue-chip companies have more motivations to invest rather than distribute the FCF as dividends despite poor investment prospects. Companies with poor investment prospects (measured by a negative NPV) have higher cost of capital, which may reduce net earnings' growth (Yeo, 2018). In this case, managers are more likely to pay low dividends, lower than the expected level of drop in the net earnings to compensate the loss in net earnings, ceteris paribus. Hence, it explains the negative and significant relationship between FCF and DPE as found in this research. This finding is consistent with that reported by Danila et al. (2020).

This research hypothesizes a positive association between LDIVD and dividend payout. Past dividend has been one of the key determinants in corporate dividend policy earliest found in Lintner (1956). Lintner stated that companies are hesitant to increase dividend payouts to a certain level as it will be difficult to sustain the amount and companies prefer to maintain a dividend payout, which is stable in the long-term. The positive relationship also can be related to Signaling theory as a drop or increase in dividend payout would be perceived as a signal to companies' current performance to the shareholders (May \& Yacob, 2018). The regression results in Table 3 show a positive relationship between LDIVD and dividend payout in both models, but the significance is reported only for DPA. Regardless, the sign of relationship is consistent to those reported in past researches (e.g., Al-Kayed, 2017; Dewasiri et al., 2018; May \& Yacob, 2018; Fitri et al., 2016), and this finding supports that bluechip companies in Malaysia pay close attention to past year's dividend and consider the signal that the investors will perceive when they issue dividend. Distributing dividends that are higher than the past year's dividend may represent positive outlooks of the companies' future cash flows, which would motivate investors to invest more in these companies in hopes of receiving higher revenue in the future. Therefore, managers of blue-chip companies are very attentive to past record of dividend payout when determining upcoming dividend payouts. The finding of this research also supports the common view that blue-chip companies are consistent when paying dividends, which levels of future dividends should move in tandem to companies' past dividends.
As reported in Table 3, MTBV is revealed to be significant and positively related to dividend payout equally for DPE and DPA, as hypothesized. The regression results show that MTBV has the largest impact on dividend payout ratio in Model B. According to Lintner (1956), investors will pay premium to companies that have higher dividend payout, which then will increase the market to book value of the companies. Relatively, since blue-chip companies are more likely to have demonstrated high market to book market value, managers of these companies will be interested in publicizing the companies' capacities to strategically contribute to future cash flows to the market, hence increasing the dividend payout. The positive and significant relationship between MTBV and dividend payout (DPE and DPA) are in line with the results of prior researches such as Forti et al. (2015), Issa (2015) and Dewasiri et al. (2018).

PROGROW in this research is hypothesized to significantly and positively relate to dividend payout. A consistent sign of relationship and significance is shown in Model B (DPA). This finding supports the arguments that managers increase dividends when guaranteed higher future cash flows and companies forecasting higher profits growth should mitigate uncertainties facing managers and pay more dividends. The positive and significant relationship as reported in Model B is consistent to those reported in past research such as Forti et al. (2015). On the other hand, the results that show a negative sign of relationship between PROGROW and DPE supports the assertion that managers of Malaysia's blue-chip companies have more motivations to invest rather than distribute earnings in the form of dividends. In this case, Malaysia's blue-chip companies pay more dividends to mitigate uncertainties, but the increment in dividend payment is lower in relative to the increment in levels of current earnings.

This research hypothesized a positive relationship between TATO and dividend payout. The effectiveness of companies in utilizing total assets to generate revenue will affect dividend payout in the sense that, every dollar invested in the companies' investment will help to increase the revenues, given the assets are utilized at maximum capacity (Jacob et al., 2017). As a result, when companies are able to generate high revenues, they will more likely pay higher dividends to shareholders. This claim is supported by the results in Model B of Table 3. TATO relates significantly and positively to DPA, but a contradictory result is shown in Model A, in which TATO reports a significant, but negative relationship with dividend payout (DPE). This research takes the view that blue-chip companies, having capabilities to efficiently allocate capital, manage expenses, disperse operational risks and optimally use their assets, are able to generate considerably high levels of revenues. In spite of the decision to distribute more dividends to shareholders in response to the increment in revenues, the increment in amount of dividends may not be as high as to the increment in the amount of revenues, resulting into lower dividend payout 
ratio. Thus, explains the significant and negative relationship between TATO and DPE, whenever the total assets of bluechip companies are utilized at optimum capacity.

Company size showed positive relationship with dividend payout in Model B, specifying that larger companies are more likely to distribute higher dividends. Based on the results shown in Table 3, company size is highly significant toward dividend payout with a confidence level of $99 \%$. Company size reflects the maturity, explaining that bluechip companies are likely to pay dividends for being a large company and having more opportunities in the engagement of new investments or are funded in other sources of financing, defeating the purpose of the companies to retain earnings for further investments. The positive and significant relationship between COZISE and DPA found in this research is in line with that reported by Forti et al. (2015). This research, however, is not able to produce similar results when specifying dividend payout with DPE.

\section{Conclusions}

This research examines the impact of systematic risk (Beta), leverage (DTE), free cash flow (FCF), lagged dividends (LDIVD), market-to-book value (MTBV), profit growth (PROGROW), total asset turnover (TATO), and company size (COSIZE) on dividend payout (DPE and DPA) of 18 blue-chip companies in Malaysia over 29 years, from 2000 to 2019. The regression results exhibit that systematic risk and free cash flow have a significant and negative impact on the dividend payout. On the other hand, past year's dividends, market-to-book value, profit growth, total asset turnover and company size are shown to significantly and positively influence dividend payout, which market-tobook value has a significant impact and consistent sign of relationship to dividend payout for both specifications. This research also reports that market-to-book value has the highest impact on dividend payout when specified by DPA. The summary on the significant levels and signs of relationship of each explanatory variable are presented in Table 4.

The findings of this research are deemed to aid the investors in examining the rightful factors to secure considerable returns and to foresee possible dividends to be paid out by the companies. It is now known that systematic risk, free cash flow, past year's dividends, market-to-book value, profit growth, total asset turnover, and company size should be focused on in this aspect. Investors that are looking to invest in Malaysia's blue-chip companies should look for companies that are more stable in terms of risk, have better past year's dividends, market to book value and profit growths, have more efficiency when utilizing assets, and larger market capitalization in relation to other companies to get the best dividend profits. Companies are recommended to adopt the dividend payout decisions that suit their investors the most. Managers must review multiple factors in order to carve out decisions on dividend payout that satisfy stakeholders' expectations. The findings of this research indicate companies that are efficient in managing their risk and total assets to generate income will pay higher dividends to the shareholders. Further, past year's dividend payouts are also an important consideration for managers as they should consider the amount of dividends have the company distributed over the years as these signals can affect how investors and the public perceive the company's future to be and might affect the company's image and share value.

Table 4: Summary of Regression Results on the Influence of Independent Variables on Dividend Payouts

\begin{tabular}{|c|c|c|c|c|c|c|c|}
\hline & Model A & Model B & & & & & \\
\hline $\begin{array}{l}\text { Dependent } \\
\text { Variables }\end{array}$ & $\begin{array}{l}\text { Dividend } \\
\text { Payout per } \\
\text { Earnings }\end{array}$ & $\begin{array}{c}\text { Dividend } \\
\text { Payout per } \\
\text { Assets }\end{array}$ & & $\begin{array}{c}\text { Significance } \\
\text { (Confidence } \\
\text { Level, \%) }\end{array}$ & $\begin{array}{l}\text { Confirmed } \\
\text { Relationship } \\
\text { Sign and } \\
\text { Significance }\end{array}$ & & \\
\hline & Actual & Actual & Expected & Model A & Model B & Model A & Model B \\
\hline BETA & + & - & - & $\mathrm{n} / \mathrm{a}$ & $99 \%$ & No & Yes \\
\hline DTE & - & - & + & $\mathrm{n} / \mathrm{a}$ & $\mathrm{n} / \mathrm{a}$ & No & No \\
\hline FCF & - & + & + & $99 \%$ & $\mathrm{n} / \mathrm{a}$ & No & Yes \\
\hline LDIVD & + & + & + & $\mathrm{n} / \mathrm{a}$ & $99 \%$ & Yes & Yes \\
\hline MTBV & + & + & + & $99 \%$ & $99 \%$ & Yes & Yes \\
\hline PROGROW & - & + & - & $\mathrm{n} / \mathrm{a}$ & $99 \%$ & Yes & No \\
\hline TATO & - & + & + & $99 \%$ & $99 \%$ & No & Yes \\
\hline COZISE & - & + & + & $\mathrm{n} / \mathrm{a}$ & $99 \%$ & No & Yes \\
\hline
\end{tabular}

Notes: Regression results on the influence of the dividend payout outputs presented in this table is consistently arranged according to the models (Model A and Model B) reported in Table 3. As significance level and sign of relationship of each of the explanatory variables are found to be both, consistent and inconsistent across models, the results are summarized as one. 
Attributable to it, managers should consider to pay more dividends to reflect the companies' capacities to strategically contribute to future cash flows to the market and increase their market value.

Regardless of the empirical evidence reported in this research on the significant determinants of dividend payout for Malaysia's blue-chip companies, future researchers are advisable to expand the research. It is recommended to compare the determinants of dividend payout of blue-chip companies with other companies listed in the other markets of Bursa Malaysia. Future research should investigate the variables that might react differently to the dividend payout of companies from other markets. Further, based on the current literature in the area of dividend payout, there are still many other variables that can influence the dividend payout ratio other than the ones used in this research, such as macroeconomic factors, other firms' specific factors (e.g., corporate tax), behavioral factors (demographic attributes) and investors preference. Examining more variables should assist future research to come up with clearer insights on the determinants of the dividend payout in Malaysia. In addition, as this research only considers the dividends distributed in the form of cash in its specifications, it is recommended that future research consider the dividends in other forms. Some companies pay dividends in other modes (e.g., shares and dividend scripts or bonds) (Jozef \& Paais, 2020). Hence, further analyses on this topic are expected to draw a conclusion on the determinants of dividend payouts in Malaysia. A uniform understanding and conclusion on the factors influencing dividend payout would assuredly assist companies in determining wiser dividend payout policy and, at the same time, offer investors better insights on the company's financial standings for better investment decisions.

\section{References}

Al-Kayed, L. T. (2017). Dividend payout policy of Islamic vs conventional banks: case of Saudi Arabia. International Journal of Islamic and Middle Eastern Finance and Management, 10(1), 117-128.

Baker, H. K., \& Weigand, R. (2015). Corporate dividend policy revisited. Managerial Finance, 41(2), 126-144.

Bhattacharya, S. (1979). Imperfect information, dividend policy, and" the bird in the hand" fallacy. The Bell Journal of Economics, 10(1), 259-270.

Chiang, Y.-C., \& Lai, B.-S. (2015). Dividend payout policy decision: the role of foreign ownership. Investment Management and Financial Innovations, 12(2), 204-213.

Danila N., Noreen. U, Azizan. N. A, Farid. M, Ahmed. Z, (2020). Growth Opportunities, Capital Structure and Dividend Policy in Emerging Market: Indonesia Case Study. Journal of Asian
Finance, Economics and Business, 7(10), 1-8. https://doi. org/10.13106/jafeb.2020.vol7.no10.001

Dewasiri, N. J., Koralalage, W. B. Y., Azeez, A. A., Jayarathne, P., Kuruppuarachchi, D., \& Weerasinghe, V. (2019). Determinants of dividend policy: Evidence from an Emerging and Developing market. Managerial Finance, 45(3), 413-429.

Eusoff, N. S. (2018). Super big-cap rally adds RM35b market capitalisation to Bursa. The Edge Market (March 12). Retrieved from https://www.theedgemarkets.com/article/super-bigcaprally-adds-rm35b-market-capitalisation-bursa

Farrukh, K., Irshad, S., Khakwani, M. S., Ishaque, S., \& Ansari, N. Y. (2017). Impact of dividend policy on shareholders wealth and firm performance in Pakistan. Cogent Business \& Management, 4(1), 1408208.

Fitri, R. R., Hosen, M. N., \& Muhari, S. (2016). Analysis of factors that impact dividend payout ratio on listed companies at Jakarta Islamic Index. International Journal of Academic Research in Accounting, Finance and Management Sciences, 6(2), 87-97.

Forti, C. A. B., Peixoto, F. M., \& Alves, D. L. e. (2015). Determinant factors of dividend payments in Brazil. Revista Contabilidade \& Finanças, 26(68), 167-180.

Franc-Dąbrowska, J., Mądra-Sawicka, M., \& Ulrichs, M. (2020). Determinants of dividend payout decisions-the case of publicly quoted food industry enterprises operating in emerging markets. Economic Research-Ekonomska Istraživanja, 33(1), 1108-1129.

Franco, M., \& Miller, M. H. (1958). The cost of capital, corporation finance and the theory of investment. The American Economic Review, 48(3), 261-297.

Gordon, S. C. (1963). A century of West Indian education: A source book (Vol. 3), Harlow, UK: Longmans.

Guizani, M. (2018). The mediating effect of dividend payout on the relationship between internal governance and free cash flow. Corporate Governance: The International Journal of Business in Society, 18(4), 748-770.

Hafeez, M. M., Shahbaz, S., Iftikhar, I., \& Butt, H. A. (2018). Impact of Dividend Policy on Firm Performance. International Journal of Advanced Study and Research Work, 1(4), 1-5.

Hill, H., Yean, T. S., \& Haji Mat Zin, R. (2013). Malaysia's Development Challenges: Graduating from the Middle. Abingdon-on-Thames, UK: Taylor \& Francis.

Issa, A. (2015). The determinants of dividend policy: Evidence from Malaysian firms. Research Journal of Finance and Accounting, 6(18), 69.

Jacob, J., Ali, F., Se, T., \& Si, M. (2017). The Impacts of The Ratio of Liquidity, Activity And Profitability Towards Company Value With Dividend Policy As Intervening Variables. Journal of Business and Management, 19(10), 1-7. https://doi. org/10.9790/487X-1910040107

Jensen, M. C. (1986). Agency costs of free cash flow, corporate finance, and takeovers. The American Economic Review, 76(2), 323-329. 
Jozef, R. P., \& Maartje, P. (2020). Effect of Liquidity, Profitability, Leverage, and Firm Size on Dividend Policy. Journal of Asian Finance, Economics and Business, 7(10), 35-42. https://doi. org/10.13106/jafeb.2020.vol7.no10.035

Kaźmierska-Jóźwiak, B. (2015). Determinants of dividend policy: evidence from polish listed companies. Procedia Economics and Finance, 23, 473-477.

Kester, W. C. (1986). Capital and ownership structure: A comparison of United States and Japanese manufacturing corporations. Financial Management, 15(1), 5-16.

Kumar, J. (2019). Behaviour Pattern of Dividend Payout: A Study on Some Selected Blue Chip Companies in India Indian Journal of Accounting (IJA), 51(2).

Lintner, J. (1956). Distribution of incomes of corporations among dividends, retained earnings, and taxes. The American Economic Review, 46(2), 97-113.

Lintner, J. (1964). Optimal dividends and corporate growth under uncertainty. The Quarterly Journal of Economics, 78(1), 49-95.

Marlim, P., \& Arifin, A. Z. (2015). Analysis of Cash Position, Debt to Equity Ratio, Return on Assets, Growth Potential, and Total Assets Turn Over Effect to Dividend Payout Ratio on Companies Listed at Indonesia Stock Sxchange 2009-2011. International Journal of Applied Business and Economic Research, 13(7), 5403-5419.

May, M. G., \& Yacob, N. (2016). The influences of company's size and past year's dividend information to the public listed companies in Malaysia. Taylor's Business Review, 7(1), 63-81.

Tahir. M., \& Mustaq, M. (2016). Determinants of Dividend Payout: Evidence from listed Oil and Gas Companies of Pakistan. Journal of Asian Finance, Economics and Business, 3(4), 25-37. https://doi.org/10.13106/jafeb.2016.vol3.no4.25

Nerviana, R. (2016). The effect of financial ratios and company size on dividend policy. The Indonesian Accounting Review, $5(1), 23-32$.

Nguyen, D. T., Bui, M. H., \& Do, D. H. (2019). The Relationship Of Dividend Policy and Share Price Volatility: A Case in Vietnam. Annals of Economics \& Finance, 20(1), 123-136.
Nyere, L., \& Wesson, N. (2019). Factors influencing dividend payout decisions: Evidence from South Africa. South African Journal of Business Management, 50(1), 1-16.

Okičić, J., \& Horvath, S. R. (2015). The Identification of Blue Chip Stocks in Underdeveloped Stock Markets of South-Eastern Europe. Economic Analysis, 48(1-2), 54-68.

Price, T. R. (2011). All About Blue Chips. T. Rower Price Investor, September 2011. https://www4.troweprice.com/ iws/wps/wcm/connect/8de0d780488308be82e5d2b2d6bd 9cbf/BlueChips.pdf?MOD=AJPERES\&CACHEID=8de0d 7 80488308be82e5d2b2d6bd9cbf

Salman, A. (2019). Determinants of dividend policy. Investment Management and Financial Innovations, 16, 167-177. doi:10.21511/imfi.16(1).2019.13

Spence, M. (2002). Signaling in retrospect and the informational structure of markets. American Economic Review, 92(3), 434459.

Suharmanto, A., Widiyanti, H. M., \& Taufik, H. (2019). Analysis of Financial Performance and Opportunity of Investment on Dividend Policy with Profitability As Moderating Variable in LQ45 Company Listed In Indoenesia Stock Exchange. International Journal of Scientific Research and Engineering Development, 2(1).

Taleb, L. (2019). Dividend Policy, Signaling Theory: A Literature Review (March 24, 2019). http://dx.doi.org/10.2139/ ssrn.3359144

Teo, L., Khong, R. W., \& Pek, C.-K. (2019). Which Is the Better Determinant for Dividends in the Kuala Lumpur Composite Index-Profitability or Cash-Flow? International Journal of Business and Society, 20(3), 1003-1021.

Turakpe, M. J., \& Fiiwe, J. L. (2017). Dividend policy and corporate performance: A multiple model analysis. Equatorial Journal of Finance and Management Sciences, 2(2), 1-16.

Yeo, H.-J. (2018). Role of free cash flows in making investment and dividend decisions: The case of the shipping industry. The Asian Journal of Shipping and Logistics, 34(2), 113-118.

Yusof, Y., \& Ismail, S. (2016). Determinants of dividend policy of public listed companies in Malaysia. Review of International Business and Strategy, 26(1), 88-99. 